"If," said he, "I live to the ordinary age, I will gather a nobler collection than we have lost." The Smithsonian Institute, which from the first had been the generous patron of the Academy, was ready to transfer to him duplicates; the Museum of Comparative Anatomy, at Cambridge, through Agassiz, its director, had invited him to go there and select from its ample stores what he desired; and learned societies at home and abroad, in response to his appeals, were forwarding to his care copies of their Transactions. Under such auspices, the members of the Academy felt that its losses would soon be restored, and that its prestige would be more commanding than ever before. They now feel that in the death of their secretary they sustain a loss which is irreparable.

Dr. Stimpson had for some years the premonitions of the disease to which he has just succumbed. Two years ago he passed the winter on the Florida coast, making extensive collections of the flora and fauna of that region. The moist, warm breath of the ocean, he thought, invigorated him. Last autumn he repaired, in company with Dr. Veille, to the same region, embarking on board one of the Coast Survey steamers to superintend the deepsea dredgings; but he had returns of hæmorrhage, which so far prostrated him as to defeat his purposes. For seventy days he remained on board, with nothing but ship fare to eat, at which his stomach revolted. Gaining the land, he was transferred to a hotel, but his physical powers were past the rallying point. Accompanied by Dr. Veille, he was at length placed on board a steamer, which landed him in Baltimore, from which place, by a short journey in a carriage, he was conveyed to Ilchester, where reside his wife's friends. Here he lingered a few weeks, dictating letters and pencilling short ones to his most intimate friends. And now comes the intelligence that the grave has closed over him, and that in his dying hours his thoughts centred on the Academy.

Dr. Stimpson had qualities which attracted, by the strongest ties, all who had personal relations with him. Modest and retiring in his disposition, the casual acquaintance little knew the vast range and the minute accuracy of his information-information gathered not simply from books, but from personal observation in every quarter of the globe. He has published enough already to create for his name an honourable place in the scientific opinion of the world; but if the full results of his labours could have been brought out, few scientific men in the country would have occupied a more commanding position.

J. W. F.

\section{THE CEYLON ELEPHANT AT THE OXFORD MUSEUM}

THERE has just arrived at the Oxford Museum the skeleton of a full-grown male Ceylon elephant. During the visit of the Duke of Edinburgh to Ceylon there were two elephant drives, or kraals, held, of which full accounts were given in the daily papers at the time. It may be remembered that at one of these kraals a large male elephant, a rogue, was driven into the terminal enclosure, together with several other smaller wild elephants. The rogue charged the tame elephants introduced amongst the wild ones, knocking them over repeatedly, and effectually preventing the process of noosing. It was at length found necessary to shoot him, in order that the remainder of the elephants might be secured.

The Governor of the island, Sir Hercules Robinson, desired that the skeleton of the animal should be preserved, and the Hon. P. C. Layard undertook the task. The elephant was covered slightly with earth, so as to protect the bones from rapacious birds; and the mound thus formed was fenced round to keep off jackals, \&c. As soon as the bones were cleaned, they were collected and transported to Colombo. Mr. Layard, with his well-known zeal for the promotion of science, took immense pains that the small bones should not be lost, and the skeleton is wonderfully perfect considering the great disadvantages under which it was prepared.

The bones were presented by Sir Hercules Robinson to the Oxford Museum, and all expenses of preparation and packing were defrayed by the colony. The skeleton was packed in two rum puncheons, under my superintendence. In packing heavy bones such as these for a long sea voyage great care must be taken, as, unless they are securely wedged into their places, they will grind against one another and get spoiled. There is nothing better than a cask for packing bones. Straw bands should first be wound round each of the large bones, and, the head having been taken out of the cask, these large bones should be jammed in as closely as possible. The interstices should be filled with smaller bones and straw, which latter should be rammed in tight with sticks. As soon as the cask is quite full the head should be put in, and that end strained up tight with its hoops. The other end of the cask should now be turned uppermost, the hoops knocked off and the bottom taken out. It will be found that a good many more bones may now be introduced from this end, which must be rammed quite full like the other. By thus packing a cask from both ends, almost absolute immobility may be secured for the contents. The elephant's skeleton is a very fine one, and I believe the only one in England of a wild specimen. The ordinary museum specimens are all from menagerie animals, the muscular ridges and tuberosities of the bones of which are always badly marked. The elephant had what is called a tush, i.e., a small short tusk on the left side. This tush is in the collection of the Duke of Edinburgh.

With the elephant arrived a Dugong, also presented to the Oxford Museum by Sir Hercules Robinson. The animal, which is a young one about $5 \mathrm{ft}$. long, was procured by Mr. Twinam, Government Agent at Jaffna. It was filled with salt and packed in charcoal. It has remained more than a year thus packed up, and is unfortunately in a very pulpy condition, although its external form is remarkably well preserved. Mr. Robertson hopes, with care, to be able to make a skeleton of it.

A case containing some humari skulls, and the skeletons and skulls of various smaller animals collected by me in Ceylon, arrived at the same time ; and a fourth case, containing skulls of all the non-European races now inhabiting Ceylon, including some of undoubted jungle Weddo, collected by Mr. B. Hartshorne, of Panwila, and late of Pembroke College, Oxford, who has for a long time been investigating the language and habits of this very interesting race, and will shortly publish a paper on the subject.

The shipping arrangements of all the cases except the last, and their transmission through the Custom-house, were carried out by Messrs. Green and Co., of Colombo, who most liberally gave their services free of expense in the cause of science.

H. N. MOSELEY

\section{SUPERFLUOUS DEVELOPMENTS AND HETEROGENESTS}

$T \mathrm{HE}$ remarkable and suggestive results of experimental research obtained by Prof. Charlton Bastian, together with the no less striking arguments which he has recently put forth in the pages of the British Medical Fournal in favour of the doctrine of Evolution, appear calculated to throw light on certain phenomena in Biology which have hitherto received but scant attention. Even if Dr. Bastian's views do not gain general acceptance, so bold an enunciation of them cari scarcely fail to be productive of the very best results, since (as has ever been held by philosophers) truth is only elicited and advanced by conflict of opinion. 